\title{
Feasibility of Lowering Soybean Planting Density without Compromising Nitrogen Fixation and Yield
}

\author{
Marcos Javier de Luca, Marco Antonio Nogueira, and Mariangela Hungria*
}

\begin{abstract}
Adjusting soybean [Glycine max (L.) Merrill] density can be critical to reduce inter-plant competition for water, nutrients, and sunlight, and to increase intercepted radiation, photosynthesis, and biomass production. The objective of this study was to evaluate the effects of soybean-population density on soybean nodulation, plant nutrient status, yield, and grain quality. Three field experiments were performed in southern Brazil with soybean cultivar BRS 284, of indeterminate growth type and maturity group 6.6, at 80,000 and 320,000 plants ha ${ }^{-1}$. For $\mathrm{N}$ supply plants were dependent either largely on biological fixation of atmospheric $\mathrm{N}$-with a naturalized population of Bradyrbizobium or inoculated with Bradyrbizobium japonicum strain CNPSo 2050 - or largely on $\mathrm{N}$ fertilizer-200 $\mathrm{kg} \mathrm{N} \mathrm{ha}^{-1}$, split-applied at sowing and $\mathrm{R} 1$ growth stage. The lower plant density resulted in increased nodulation parameters (number and mass), but plant nutritional status-evaluated by the diagnosis and recommendation integrated system (DRIS) method-in general was not affected. Seed oil content increased by $3.4 \%$, but protein decreased by $4.5 \%$ at the lower plant density. The $\mathrm{N}$ source affected nodulation, but not nutritional status or grain yield. Although plant density was reduced by $75 \%$, yield decreased by $16 \%$ during only one of the three cropping seasons. These results indicate a high plasticity of soybean to adapt photosynthesis and $\mathrm{N}$ fixation to different plant densities. Furthermore, planting at the lower density has the advantages of lower input costs and less susceptibility to environmental and plant nutritional stresses.
\end{abstract}

On a dry-weight basis, about $40 \%$ of the grain of soybean is composed of protein, resulting in high demand for $\mathrm{N}$, most of which can be provided by the biological $\mathrm{N}$ fixation (Hungria et al., 2006a, 2006b). A major step in the soybean-Bradyrhizobium symbiosis is the translocation of C-rich compounds, generated by photosynthesis, to provide energy and $\mathrm{C}$ skeletons for the synthesis of $\mathrm{N}$-rich compounds in the root nodules that, in turn, are transported to the host plant shoot (Williams et al., 1982; Neves and Hungria, 1987; Kaschuk et al., 2009). Under favorable cropping conditions, both photosynthesis and biological $\mathrm{N}$ fixation are reciprocally up-regulated to support soybean's demand on C and N needs (Kaschuk et al., 2010a; Kaschuk et al., 2012), such that not only higher yields but also higher grain protein are produced when legumes rely on symbiosis (Hungria et al., 2006b; Kaschuk et al., 2010b).

Supplemental material available online. M.J. de Luca, Instituto Nacional de Tecnología Agropecuária (INTA), Rivera Indarte $722^{\circ} 216$ (5000), Córdoba, Argentina; M.J. de Luca, M.A. Nogueira, and M. Hungria, Embrapa Soja, C.P. 231, 86001-970, Londrina, Paraná, Brazil; M.J. de Luca, M.A. Nogueira, and M. Hungria Universidade Estadual de Londrina, Dep. Microbiologia, C.P. $10011,86057-970$, Londrina. Received 6 May $2014 .{ }^{*}$ Corresponding author(mariangela.hungria@embrapa.br).

Published in Agron. J. 106:2118-2124 (2014)

doi:10.2134/agronj14.0234

Available freely online through the author-supported open access option. Copyright (c) 2014 by the American Society of Agronomy, 5585 Guilford Road, Madison, WI 53711. All rights reserved. No part of this periodical may be reproduced or transmitted in any form or by any means, electronic or mechanical, including photocopying, recording, or any information storage and retrieval system, without permission in writing from the publisher.
Sun light quality and quantity directly affect photosynthesis and impact yield. In soybean, the most critical stage is from flowering to the middle of the reproductive cycle or even later; high growth rates during this period increase the number of seeds per pod and plant and hence optimize crop yield (Andrade et al., 2002). From flowering on, if availability of light in the lower part of the canopy is low due to mutual shading by other plants, abscission of flowers and developing pods can be high, reducing yield (Johnston et al., 1969). Qualitative changes in the ratio of red to infrared light through the canopy also affect photosynthesis (Kasperbauer, 1987), regulating the ultrastructure of chloroplasts, partitioning of carbohydrates into the cells, photosynthetic efficiency and the concentrations of several metabolites (Kasperbauer, 1987). It is also noteworthy that the light intensity and quality can affect partitioning of protein, oil, and fatty acids in soybean seeds (Bellaloui and Gillen, 2010).

Light quality and quantity also affect several steps of the symbiosis (Lie, 1969; Balatti and Montaldi, 1986; Neves and Hungria, 1987). Starting with the rhizosphere, light modifies root exudation both quantitatively and qualitatively (Neumann and Römheld, 2000), affecting rhizospheric microorganisms. Red-light-treated plants also allocate more photosynthates to the roots (Kasperbauer et al., 1984; Kasperbauer, 1987), promoting nodule number. In addition, changes in the red to infrared ratio affect the onset of nodule formation (Lie, 1969).

Abbreviations: DRIS, diagnosis and recommendation integrated system; NBI, nutritional balance index. 
The effects of plant density represent an intriguing subject for a study, potentially with profound implications for farmers' profits. High plant density for soybean is often recommended to achieve high yields, and in Brazil most farmers adopt the density of 300,000 plants ha ${ }^{-1}$. However, decreased seeding rates may result in lower sowing costs, reduced competition for water, nutrients, and sunlight and increased radiation penetration to lower branches, altogether improving yield and farmer's income (Board et al., 1990,1992; de Luca and Hungria, 2014). It is also important to consider that soybean seed cost accounts for 10 to $13 \%$ of overall costs of soybean production in Brazil (CONAB, 2014), and any agronomical practice that decreases cost production without affecting productivity on a land area bases should be considered for an efficient farm planning.

The aim of this study was to evaluate the effects of reducing plant density on nodulation, plant nutrition, yield, and quality of soybean seeds. The hypothesis was that, by reducing planting density there will be compensatory changes in the photosynthetic and biological $\mathrm{N}$ fixation processes that may positively impact per plant and total yields.

\section{MATERIALS AND METHODS}

\section{Field Site Description and Procedures before Sowing}

The experiments were performed for three consecutive cropping seasons - 2010/2011, 2011/2012, and 2012/2013 - at the experimental station of Embrapa Soja in Londrina, State of Paraná, southern Brazil $\left(23^{\circ} 11^{\prime} \mathrm{S}, 51^{\circ} 11^{\prime} \mathrm{W}\right.$, elevation of $620 \mathrm{~m}$ ). The soil is classified as Latossolo Vermelho Distroférrico (Brazilian classification system; Typic Hapludox, USDA soil taxonomy). The average annual temperature is $21^{\circ} \mathrm{C}$, with an average high of $28.5^{\circ} \mathrm{C}$ in February and low of $13.3^{\circ} \mathrm{C}$ in July. Average annual rainfall is $1651 \mathrm{~mm}$, with $123 \mathrm{~d}$ of rainfall per year; maximum rainfall occurs in the summer (JanuaryMarch) and minimum in winter (June-August). According to Köeppen's classification, the climate is subtropical humid ( $C f a$ : humid, subtropical, with hot summers).

Lime was applied to the soil 6 mo before the first experiment, based on the soil chemical analysis, aiming to increase base saturation to $70 \%$ (Embrapa, 2011).

About $40 \mathrm{~d}$ before sowing, 20 soil subsamples were collected from the 0 - to 20 -cm soil layer. Each set of 20 soil subsamples was combined into one composite sample, and four composite samples were taken for chemical, granulometric, and microbiological analyses.

For chemical analysis (Pavan et al., 1992), samples were ovendried $\left(60^{\circ} \mathrm{C}, 48 \mathrm{~h}\right)$ and sieved $(2 \mathrm{~mm})$. Soil $\mathrm{pH}$ was determined in $0.01 \mathrm{M} \mathrm{CaCl}_{2}$ (1:2.5; soil/solution) after $1 \mathrm{~h}$ shaking. Calcium, $\mathrm{Mg}$, and $\mathrm{Al}$ contents were determined in $1 \mathrm{M} \mathrm{KCl}$ (1:10; soil/solution) extracts after $10 \mathrm{~min}$ shaking. Phosphorus and $\mathrm{K}$ contents were determined in Mehlich-1 extract $(0.05 \mathrm{M}$ $\mathrm{HCl}+0.0125 \mathrm{M} \mathrm{H}_{2} \mathrm{SO}_{4} ; 1: 10$ soil/solution) after shaking for $10 \mathrm{~min}$. Aluminum was determined by titration with $0.015 \mathrm{M}$ $\mathrm{NaOH}$, with bromothymol blue as indicator. Calcium and $\mathrm{Mg}$ concentrations were determined in an atomic absorption spectrophotometer, $\mathrm{K}$ in a flame photometer, and $\mathrm{P}$ by colorimetry, by the molybdenum blue/ascorbic acid method. Carbon was determined by dichromate oxidation. Soilchemical characteristics are presented in Table 1.
Soil granulometric fractions were determined according to Embrapa (1997) and consisted of $\left(\mathrm{g} \mathrm{kg}^{-1}\right): 710$ (clay), 82 (silt), 208 (sand).

Soybean bradyrhizobia population was estimated by the most probable number (MPN) method using soybean cultivar BRS 284 as trap host (Vincent, 1970), and the results for each year are shown in Table 1.

\section{Treatments, Experimental Design, and Crop Management}

The experiments consisted of six treatments, applied at the same site for three cropping seasons, as follows: (i) Noninoculated (naturalized population of Bradyrbizobium), 80,000 plants ha ${ }^{-1}$ (T1); 2) Non-inoculated (naturalized population of Bradyrbizobium), 320,000 plants ha ${ }^{-1}$ (T2); 3) Non-inoculated control $+\mathrm{N}$ fertilizer, 80,000 plants ha ${ }^{-1}$ (T3); 4) Non-inoculated control $+\mathrm{N}$ fertilizer, 320,000 plants ha ${ }^{-1}$ (T4); 5) Inoculated with Bradyrbizobium japonicum strain CNPSo 2050, 80,000 plants ha ${ }^{-1}$ (T5); 6) Inoculated with B. japonicum strain CNPSo 2050, 320,000 plants ha ${ }^{-1}$ (T6).

The experiment had a completely randomized block design, with six replicates. Each plot measured $4 \mathrm{~m}$ in width by $10 \mathrm{~m}$ in length. Plots had eight lines, with $0.5 \mathrm{~m}$ between lines. Sowing was performed to deliver 8 seeds $\mathrm{m}^{-2}+10 \%$ (considering the seed germination rate of $90 \%$ ) in the 80,000 plants ha $\mathrm{h}^{-1}$ density and 32 plants $\mathrm{m}^{-2}+10 \%$ in the treatment with 320.000 plants $\mathrm{ha}^{-1}$; population densities were confirmed after germination. The plots were separated by $0.5 \mathrm{~m}$-wide rows and $1.5 \mathrm{~m}$-wide terraces to avoid cross contamination from surface flushes containing bacteria and/or fertilizers caused by heavy rainfall. The cultivar used was BRS 284 (genealogy Mycosoy- $45 \times$ Suprema), of indeterminate growth type and maturity group 6.6. Dates of sowing were 3 Nov. 2010, 9 Nov. 2011, and 29 Oct. 2012. At sowing, $300 \mathrm{~kg} \mathrm{ha}^{-1}$ of fertilizer, with the formulation $0-20-20$, were applied in bands in the sowing line.

Inoculated treatments received a liquid inoculant prepared with B. japonicum strain CNPSo 2050, an isolate from Cordoba's region, Argentina. A peat inoculant was prepared at the concentration of $10^{9} \mathrm{CFU} \mathrm{g}^{-1}$ and applied to supply 1.2 million cells seed $^{-1}$. Seeds were not treated with fungicides or insecticides. Non-inoculated treatments (with the naturalized population of Bradyrbizobium, as the soil had received inoculants in previous years) without and with $\mathrm{N}$ fertilizer were included; the latter consisted of $200 \mathrm{~kg} \mathrm{ha}^{-1}$ of $\mathrm{N}$ as urea, $50 \%$ at sowing and $50 \%$ as topdressing at the $\mathrm{R} 1$ growth stage (beginning of flowering, that is, plants with at least one flower on any node, Fehr et al., 1971).

At the V4 stage (four unfolded trifoliolate leaves, scale of Fehr et al., 1971) Co $\left(2.5 \mathrm{~g} \mathrm{ha}^{-1}\right)$ and Mo $\left(20 \mathrm{~g} \mathrm{ha}^{-1}\right)$ were supplied by leaf pulverization. During plant growth cycle, the following products were used: herbicides Clorimuron $\left(50 \mathrm{~g} \mathrm{ha}^{-1}\right)$ and Cletodim $\left(0.4 \mathrm{~L} \mathrm{ha}^{-1}\right)$; insecticides Diflubenzuron $\left(80 \mathrm{~g} \mathrm{ha}^{-1}\right)$, Thiametoxam + Lambdacihalotrina $\left(200 \mathrm{~mL} \mathrm{ha}^{-1}\right)$.

The experiments were not irrigated, and water was provided only by natural rainfall. 
Table I. Soil chemical properties $(0-20 \mathrm{~cm})$ and soybean Bradyrhizobium population before sowing in 2010, 2011 , and 2012 .

\begin{tabular}{|c|c|c|c|}
\hline Properties & 2010 & 2011 & 2012 \\
\hline $\mathrm{Ca}, \mathrm{cmol}_{\mathrm{c}} \mathrm{dm}^{-3}$ & 4.2 & 3.9 & 4.0 \\
\hline $\mathrm{Mg}, \mathrm{cmol}_{\mathrm{c}} \mathrm{dm}^{-3}$ & 1.9 & 1.7 & 1.4 \\
\hline $\mathrm{K}, \mathrm{cmol}_{\mathrm{c}} \mathrm{dm}^{-3}$ & 0.6 & 0.9 & 0.7 \\
\hline $\mathrm{S}_{-} \mathrm{SO}_{4}, \mathrm{mg} \mathrm{dm}^{-3}$ & 6.8 & 6.4 & 7.0 \\
\hline $\mathrm{P}, \mathrm{mg} \mathrm{dm} \mathrm{m}^{-3}$ & 15.4 & 19.1 & 28.9 \\
\hline CEC $\mathrm{pH} 7, \mathrm{cmol}_{\mathrm{c}} \mathrm{dm}^{-3}$ & 12.8 & 11.0 & 10.6 \\
\hline CEC-effective, $\mathrm{cmol}_{\mathrm{c}} \mathrm{dm}^{-3}$ & 6.7 & 6.4 & 6.2 \\
\hline Base saturation, $\vee \%$ & 52.8 & 58.1 & 58.1 \\
\hline $\mathrm{pH}$ in $\mathrm{CaCl}_{2}$ & 4.9 & 5.1 & 5.2 \\
\hline Potential acidity $(\mathrm{H}+\mathrm{Al})$ & 6.0 & 4.6 & 4.4 \\
\hline $\begin{array}{l}\text { Bradyrhizobium population, } \\
\text { CFU g goil }\end{array}$ & $1.79 \times 10^{4}$ & $9.17 \times 10^{3}$ & $3.85 \times 10^{4}$ \\
\hline
\end{tabular}

\section{Plant Analyses and Statistics}

At the R1 growth stage, plants were evaluated for nodulation and nutrient content. For nodulation, eight plants per replicate were randomly collected, excluding the central area $\left(8 \mathrm{~m}^{2}\right)$ of the plot that was left for grain yield-evaluation at physiological maturity. Plant collection was carefully performed with a shovel to include most of the root system and fallen nodules.

In the laboratory, roots and shoots were separated, and nodulated roots were carefully washed and oven-dried at $65^{\circ} \mathrm{C}$ for approximately $72 \mathrm{~h}$. Nodules were then removed from roots and allowed to dry for another $72 \mathrm{~h}$ before counting and weighing. The parameters evaluated for nodulation were number of nodules per plant, dry weight per nodule, and nodule dry weight per plant.

Also at the R1 growth stage, 30 recently matured leaves with petioles were collected per plot to evaluate plant nutrient status. At the laboratory the leaves were carefully washed with distilled water, oven dried $\left(65^{\circ} \mathrm{C}\right.$ for approximately $72 \mathrm{~h}$ ) and ground ( $35 \mathrm{mesh})$. Total-N content was determined in a sulfuric acid extract, while $\mathrm{P}, \mathrm{K}, \mathrm{Ca}, \mathrm{Mg}$, and $\mathrm{S}$ were determined in a nitric-perchloric extract. The nutritional status was evaluated by applying the DRIS method (Beaufils, 1973). The $\mathrm{C}$ content was determined in a total organic carbon (TOC) analyzer (Elementary model Cube).

Further analyses performed in the same 30 recently matured leaves with petioles collected at the $\mathrm{R} 1$ stage included ( $\mathrm{mmol} \mathrm{kg}{ }^{-1} \mathrm{dry}$ weight): ammonium, amide, nitrate, ureides and total nitrogenous compounds (ammonium + amide + nitrate + ureides), performed as described before (Boddey et al., 1987; Hungria and Kaschuk, 2014).
At physiological maturity, plants in the $8 \mathrm{~m}^{2}$ central part of each plot were harvested. Parameters estimated were grain yield (corrected to 13\% moisture content), dry weight per grain and number of grains per plant.

Oil and protein contents in grains were also determined. Lipid content (oil) was determined in milled grains (Tecnal, model TE-651) in a Soxhlet extractor (Tecnal, model sebelin TE-188), using $n$-hexane as solvent and following the methodology of Instituto Adolfo Lutz (2008). Protein content was evaluated in a NIR analyzer Thermo brand (model FTIR Antaris II).

The data were analyzed using the Infostat software (Di Rienzo et al., 2009). All assumptions required by the analysis of variance were verified. Means were compared using Fisher's test at $p<0.05$.

\section{RESULTS AND DISCUSSION}

\section{Nodulation, Nitrogenous Compounds, and Carbon Content in Leaves}

Nodule number and dry weight were higher in the low plant density treatment, of 80,000 plants $^{-1} \mathrm{a}^{-1}$, with both the naturalized soybean bradyrhizobia soil population (T1) and in the treatment inoculated with B. japonicum strain CNPSo 2050 (T5); in addition, as expected, nodulation was substantially reduced by the addition of $\mathrm{N}$ fertilizer (Table 2). Considering the average of treatments $\mathrm{T} 1$ and $\mathrm{T} 5$, nodule number and dry weight were 52 and $24 \%$ higher, respectively, than the average of the treatments with high plant density, T2 and T6. However, specific dry weight per nodule was higher in the high plant density treatments (Table 2), probably reflecting a compensatory mechanism for the lower number of nodules.

Plant density and architecture affect the quantity and quality of light available to the lower canopy, with consequences for nodulation. First, light availability and photosynthesis are directly related to the amount of $\mathrm{C}$ available for nodule formation (Neves and Hungria, 1987). Qualitatively, it has been long shown that nodulation is controlled by the phytochrome system, being favored by red light $(\mathrm{R})$ and inhibited by infrared radiation (IR) (Lie, 1969; Balatti and Montaldi, 1986). Recently, it was confirmed that phytochrome $\mathrm{B}($ phy $B)$ is part of a monitoring system that detects suboptimal light conditions (Suzuki et al., 2011). In Lotus japonicum phyB mutants, nodulation by Mesorbizobium loti was significantly reduced and, in the same study, nodulation of wild-type plants was dramatically reduced when exposed to low $\mathrm{R} / \mathrm{IR}$ ratio. In addition, the synthesis of jasmonic acid (JA) decreased in $p h y B$ mutants and also under low R/IR conditions. Altogether, these

Table 2. Effects of plant density on nodulation (nodule number, NN; nodule dry weight, NDW; specific NDW) of soybean at the RI stage. Nitrogen treatments consisted of non-inoculated control, non-inoculated control receiving $\mathrm{N}$ fertilizer $\left(200 \mathrm{~kg} \mathrm{ha}^{-1}\right.$ of N supplied as urea, split at sowing and at RI), or inoculated with B. japonicum strain CNPSo 2050.

\begin{tabular}{|c|c|c|c|c|}
\hline Treatment & Density & NN & NDW & Specific NDW \\
\hline & plants ha ${ }^{-1}$ & no. plants ${ }^{-1}$ & mg plants ${ }^{-1}$ & mg nodule ${ }^{-1}$ \\
\hline TI-Non-inoculated & 80,000 & 81.8a† & $264.9 \mathrm{a}$ & $3.6 \mathrm{c}$ \\
\hline T2-Non-inoculated & 320,000 & $54.9 \mathrm{~b}$ & 222. Ibc & 4. Iab \\
\hline T3-N-fertilizer & 80,000 & $48.9 \mathrm{~b}$ & $123.1 \mathrm{~d}$ & $2.7 \mathrm{e}$ \\
\hline T4-N-fertilizer & 320,000 & $33.7 c$ & $102.4 d$ & $3.1 d$ \\
\hline T5-Inoculated & 80,000 & $71.9 a$ & $254.0 \mathrm{ab}$ & $4.0 \mathrm{~b}$ \\
\hline T6-Inoculated & 320,000 & $46.5 b c$ & $196.8 \mathrm{c}$ & $4.4 \mathrm{a}$ \\
\hline
\end{tabular}

$\dagger$ Means of three crop seasons, each with six replicates. Different letters indicate significant difference (Fisher's test, $p<0.05$ ). 
results suggest that $\mathrm{JA}$ is a positive regulator of nodulation in L. japonicum, being photomorphogenetically controlled by sensing the R/IR ratio (Suzuki et al., 2011). Supporting these results, in the soybean-Bradyrhizobium symbiosis it has been shown that increases in methyl jasmonate result in higher nodulation (Mabood et al., 2006). Consequently, we may hypothesize that, in our study, low ratios of R/IR under high plant density were perceived by the phytochrome $\mathrm{B}$ and reduced the expression of JA-related genes, resulting in decreased nodulation.

In relation to the $\mathrm{N}$ compounds in recently matured leaves (collected according to the procedures specified for the DRIS analysis), for ammonium, amide and nitrate no differences were related to plant density (Table 3). Lower values were found in the non-inoculated plants, and nitrate content was higher in $\mathrm{N}$-fertilized plants at low density. In contrast, $\mathrm{N}$-ureides were about $100 \%$ higher under high density, whereas total- $\mathrm{N}$ values were higher in $\mathrm{N}$-fertilized plants, independently of the plant density (Table 3).

One hypothesis for the higher $\mathrm{N}$-ureides contents in plants under high population density is that the decrease in light density and the low $\mathrm{R} / \mathrm{IR}$ ratio accelerated senescence in the lower canopy and favored remobilization to the upper leaves. Indeed, visual observation was that senesced leaves in the lower canopy were far more abundant under high density. Senescence can occur in the whole plant, at the organ and at the cellular levels, and light - mediated by $p h y B$ - is one of the specific signals affecting plant senescence (Ballaré and Casal, 2000). This process could be orchestrated with the up-regulation of gene expression of xanthine dehydrogenase (XDH), a key enzyme in the synthesis of ureides. In Arabidopsis, it has been shown that XDHs also produce superoxide radicals, which may be involved in stress responses that require reactive oxygen species (Juvany et al., 2013). Therefore, increases in activity of XDHs may result in more ureides under high population density, representing an additional source of reactive oxygen species and helping in the photooxidative stress observed in lower leaves.

For all three cropping seasons, shoot dry weight (data not shown) and $\mathrm{C}$ contents in leaves were higher in the $\mathrm{N}$-fertilized plants with 80,000 plants $\mathrm{ha}^{-1}$, suggesting higher photosynthetic rates (Table 3). In 2011/2012 the plants suffered with severe drought, with the water deficit estimated at $132 \mathrm{~mm}$ from sowing to R1, whereas in 2010/2011 and $2012 / 2013$ rainfall was in a normal range (data not shown). In the year with drought stress, photosynthetic rates were reduced and so was C content in leaves; C was lower in 2011/2012 (mean of $39.0 \%$ for all treatments) than in 2010/2011 (40.3\%) and $2012 / 2013$ (40.5\%).

\section{Nutritional Diagnosis}

Based on the DRIS index for nutritional diagnosis, no deficiencies of $\mathrm{P}, \mathrm{K}, \mathrm{Ca}$, and $\mathrm{S}$ were observed, indicating that the status of these elements was not affected by plant density or $\mathrm{N}$ treatment; a slight imbalance was observed for Ca only in the T4 treatment, $\mathrm{N}$ fertilized and with the high population density (Table 4). For Mg, imbalance was observed in all treatments and although without statistical differences, there was a tendency of being more drastic under the high population density (Table 4).

Intriguingly, DRIS indicated imbalance of $\mathrm{N}$ in all treatments (Table 4), and this was observed in all three cropping seasons (data not shown). Nitrogen imbalance detected by DRIS has been previously reported by Harger et al. (2003) with four soybean cultivars-Embrapa 48, BRS 132, BRS 133, and BRS 134-belonging to different maturation cycles. It is worth mentioning that although $\mathrm{N}$ contents in leaves were higher in the dry year of $2011 / 2012$, probably as a result of concentration in a lower biomass of leaves due to the severe drought stress (Fig. 1), the $\mathrm{N}$ deficit detected by DRIS

Table 3. Effects of plant density on the composition of $\mathrm{N}$ (mmol kg-1 dry weight) and C content (\%) in soybean leaves at the RI stage. Nitrogen treatments consisted of non-inoculated control, non-inoculated control receiving $\mathrm{N}$-fertilizer ( $200 \mathrm{~kg} \mathrm{ha}^{-1}$ of $\mathrm{N}$ supplied as urea, split at sowing and at RI), or inoculated with B. japonicum strain CNPSo 2050.

\begin{tabular}{|c|c|c|c|c|c|c|c|}
\hline $\mathrm{N}$ source & Density & Ammonium & Amide & Nitrate & Ureides & Total N & C \\
\hline & plant ha-1 & +2 & $\mathrm{~mm}$ & dry weigl & + & 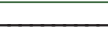 & $\%$ \\
\hline TI-Non inoculated & 80,000 & $22.6 \mathrm{~b} t$ & $33.1 \mathrm{c}$ & $225.5 \mathrm{bc}$ & $14.1 \mathrm{~b}$ & $295.4 b$ & $40.35 b$ \\
\hline T2-Non inoculated & 320,000 & $22.4 b$ & $32.5 c$ & $209.2 c$ & $29.4 a$ & $293.1 \mathrm{~b}$ & $40.05 b$ \\
\hline T3-N-fertilizer & 80,000 & $26.6 a b$ & $38.2 \mathrm{ab}$ & $255.7 \mathrm{a}$ & $17.4 \mathrm{~b}$ & $337.9 a$ & $43.40 \mathrm{a}$ \\
\hline T4-N-fertilizer & 320,000 & $26.7 \mathrm{ab}$ & $38.7 \mathrm{a}$ & 244.0ab & 26. Ia & $335.4 a$ & $38.45 b$ \\
\hline T5-Inoculated & 80,000 & $27.6 a$ & $36.0 \mathrm{abc}$ & $240.6 \mathrm{ab}$ & $14.2 \mathrm{~b}$ & $318.4 \mathrm{ab}$ & $39.35 b$ \\
\hline T6-Inoculated & 320,000 & $23.9 \mathrm{ab}$ & $34.2 b c$ & $208.8 c$ & 29.1a & $296.0 b$ & $39.55 b$ \\
\hline
\end{tabular}

$\dagger$ Means of three crop seasons, each with six replicates. Different letters indicate significant difference (Fisher's test, $p<0.05)$.

Table 4. Diagnosis and recommendation integrated system (DRIS) evaluated in recently matured soybean leaves collected at RI stage. N treatments consisted of non-inoculated control, non-inoculated control receiving $\mathrm{N}$-fertilizer ( $200 \mathrm{~kg} \mathrm{ha}^{-1}$ of $\mathrm{N}$ supplied as urea, split at sowing and at $\left.\mathrm{RI}\right)$, or inoculated with B. japonicum strain CNPSo 2050.

\begin{tabular}{|c|c|c|c|c|c|c|c|}
\hline $\mathrm{N}$ source & Density & $\mathrm{P}$ & $\mathrm{K}$ & $\mathrm{Ca}$ & $\mathrm{Mg}$ & $\mathrm{S}$ & $\mathrm{N}$ \\
\hline & plant ha ${ }^{-1}$ & & & & & & \\
\hline TI-Non inoculated & 80,000 & $0.7 \mathrm{la}+$ & $1.22 b c$ & $0.1 \mathrm{la}$ & $-1.00 \mathrm{ab}$ & $0.27 c$ & $-1.85 a$ \\
\hline T2-Non inoculated & 320,000 & $0.7 \mathrm{Ia}$ & $1.25 \mathrm{abc}$ & $0.13 a$ & $-1.08 a b$ & $0.35 c$ & $-1.90 \mathrm{ab}$ \\
\hline T3-N-fertilizer & 80,000 & $0.50 \mathrm{a}$ & $1.03 c$ & $0.09 \mathrm{ab}$ & $-0.87 a$ & $0.76 a$ & $-1.84 a$ \\
\hline T4-N-fertilizer & 320,000 & $0.68 \mathrm{a}$ & $1.44 \mathrm{a}$ & $-0.06 b$ & $-1.15 a b$ & $0.68 \mathrm{ab}$ & $-1.53 a$ \\
\hline T5-Inoculated & 80,000 & $0.73 a$ & $1.20 \mathrm{bc}$ & $0.10 \mathrm{a}$ & $-0.96 a b$ & $0.21 \mathrm{c}$ & $-2.85 b$ \\
\hline T6-Inoculated & 320,000 & $0.72 \mathrm{a}$ & I.39ab & $0.02 \mathrm{ab}$ & $-1.29 b$ & $0.40 \mathrm{bc}$ & $-1.49 \mathrm{a}$ \\
\hline
\end{tabular}

$\dagger$ Means of three crop seasons, each with six replicates. Different letters indicate significant difference (Fisher's test, $p<0.05)$. 


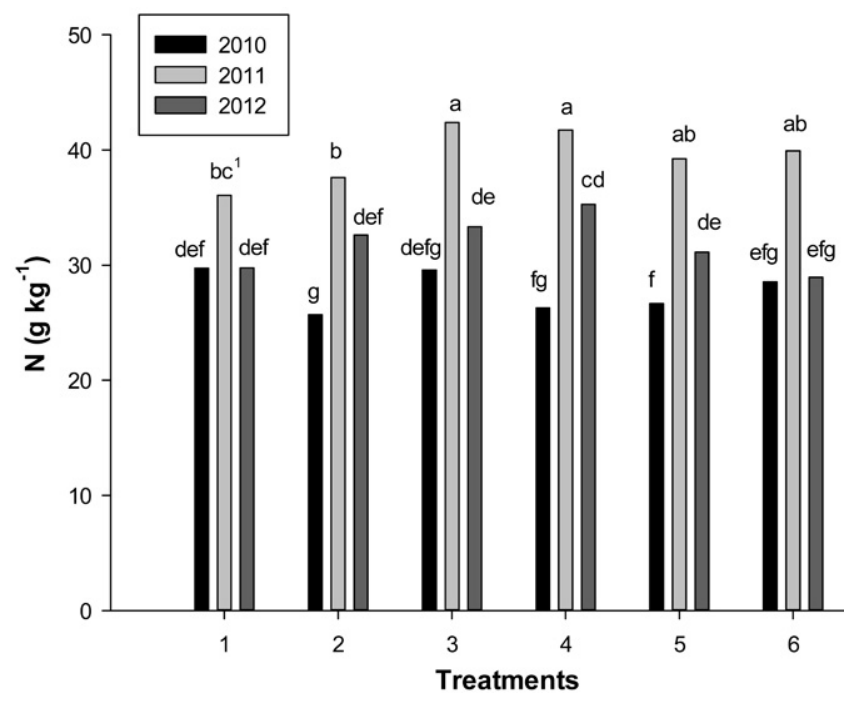

Fig. I. Nitrogen concentration $\left(\mathrm{g} \mathrm{kg}^{-1}\right)$ in recently matured soybean leaves collected at RI, in three crop seasons. Treatments: (I) Noninoculated control, 80,000 plants ha ${ }^{-1}$; (2) Non-inoculated control, 320,000 plants ha ${ }^{-1} ;$ (3) Non-inoculated control $+\mathrm{N}$ fertilizer, 80,000 plants $\mathrm{ha}^{-1}$; (4) Non-inoculated control $+\mathrm{N}$ fertilizer, 320,000 plants ha ${ }^{-1} ;(5)$ Inoculated with B. japonicum strain CNPSo 2050, 80,000 plants ha ${ }^{-1}$; (6) Inoculated with B. japonicum strain CNPSo 2050, 320,000 plants ha- ${ }^{-1}$. Data represent means of six replicates. Different letters indicate significant difference (Fisher's test, $p<0.05$ ).

occurred independently of water availability (data not shown). However, we cannot disregard the possibility that the detection of $\mathrm{N}$ imbalance could result from limitations in the database. The use of DRIS is relatively recent in Brazil, and there is need to expand the database-comprising more genotypes - with an emphasis on the introduction of genotypes of indeterminate growth type, under different soil and climatic conditions.

The sum of DRIS indices generates the nutritional balance index (NBI), and the higher the NBI, the greater is the nutritional imbalance, affecting yield negatively (Serra et al., 2013). In our study, although some nutritional imbalance was observed, no consistent differences were observed between treatments, but they were observed between the dry season of 2011/2012 and the other two seasons with regular rainfall (Supplementary Fig. S1).

Overall, we should note that using DRIS (Table 4) or NBI (Supplementary Fig. S1) plant densities did not affect soybean leaf nutritional balances.

\section{Yield Parameters and Seed Composition}

There were no differences in yield among the treatments in the first two seasons (Table 5), and it is worth mentioning again that 2011/2012 was very dry, resulting in low yields. In $2012 / 2013$ grain yields were higher in the treatments with 320,000 plants ha $^{-1}$ when compared with the density of 80,000 plants $^{-1} \mathrm{a}^{-1}$, although statistically significantly only in the case of $\mathrm{N}$-fertilized plants. Considering all treatments, high population density resulted in a yield increase of $16 \%$ in comparison to the low population density in this crop season. Therefore, these results confirm the high plasticity of soybean, once although there was a fourfold difference in plant population (i.e., $75 \%$ reduction), the mean decrease in yield, considering all three cropping seasons, was of $275 \mathrm{~kg} \mathrm{ha}^{-1}$, corresponding to only $10 \%$ (Table 5). Recently, in a field experiment with soybean at densities ranging from 40,000 to 320,000 plants ha $^{-1}$, de Luca and Hungria (2014) observed significant decreases in yield only for the very low density of 40,000 plants ha $^{-1}$, confirming the high plasticity of the plant to adapt photosynthesis and $\mathrm{N}$ fixation to different densities.

Low population density resulted in a 2.6 -fold increase in the number of seeds per plant (Table 6). Although in general there was a decrease in the dry weight per grain at low population density, considering all treatments the values were similar at

Table 5. Effects of $\mathrm{N}$ source and plant density on soybean grain yield ( $\left.\mathrm{kg} \mathrm{ha}^{-1}\right)$. Nitrogen treatments consisted of non-inoculated control, non-inoculated control receiving $\mathrm{N}$ fertilizer $\left(200 \mathrm{~kg} \mathrm{ha}^{-1}\right.$ of $\mathrm{N}$ supplied as urea, split at sowing and at RI), or inoculated with B. japonicum strain CNPSo 2050 .

\begin{tabular}{|c|c|c|c|c|c|}
\hline \multirow[b]{2}{*}{$\mathrm{N}$ source } & \multirow[b]{2}{*}{ Density } & \multicolumn{3}{|c|}{ Crop seasont } & \multirow{2}{*}{$\begin{array}{c}\text { Mean } \neq \\
3-y r\end{array}$} \\
\hline & & $2010 / 2011$ & $2011 / 2012$ & $2012 / 2013$ & \\
\hline & plants ha-l & 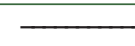 & 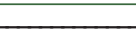 & I & \\
\hline TI-Non inoculated & 80,000 & $3453 a$ & $1338 a$ & $2628 b$ & $2473 c d$ \\
\hline T2-Non inoculated & 320,000 & $366 \mathrm{Ia}$ & $1530 \mathrm{a}$ & $3205 a b$ & $2799 a$ \\
\hline T3-N-fertilizer & 80,000 & $3704 a$ & $1442 \mathrm{a}$ & $2638 b$ & $2593 b c$ \\
\hline T4-N-fertilizer & 320,000 & $3723 a$ & $1387 \mathrm{a}$ & $3308 a$ & $2806 a$ \\
\hline T5-Inoculated & 80,000 & $3692 a$ & $132 \mid \mathrm{a}$ & $2627 b$ & $2372 d$ \\
\hline T6-Inoculated & 320,000 & $3558 a$ & $1533 a$ & $2875 a b$ & $2656 \mathrm{ab}$ \\
\hline
\end{tabular}

† Means of six replicates per crop season and different letters indicate significant difference (Fisher's test, $p<0.05$ ).

$\ddagger$ Means of three crop seasons, each with six replicates. Different letters indicate significant difference (Fisher's test, $p<0.05$ ).

Table 6. Effects of $\mathrm{N}$ source and plant density on soybean grain yield-related parameters and grain quality. Nitrogen treatments consisted of noninoculated control, non-inoculated control receiving $\mathrm{N}$ fertilizer $\left(200 \mathrm{~kg} \mathrm{ha}^{-1}\right.$ of $\mathrm{N}$ supplied as urea, split at sowing and at $\left.\mathrm{RI}\right)$, or inoculated with $B$. japonicum strain CNPSo 2050.

\begin{tabular}{|c|c|c|c|c|c|}
\hline $\mathrm{N}$ source & Density & Number of grains & Dry weight of grains & Oil content & Protein content \\
\hline & plants ha-l & no. plants $^{-1}$ & g grain $^{-1}$ & 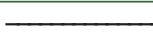 & - \\
\hline TI-Non inoculated & 80,000 & $344 a \dagger$ & $0.116 c$ & $22.7 \mathrm{a}$ & $34.4 \mathrm{bc}$ \\
\hline T2-Non inoculated & 320,000 & $128 \mathrm{~b}$ & $0.121 \mathrm{a}$ & $21.7 b$ & 36. Ia \\
\hline T3-N-fertilizer & 80,000 & $354 a$ & $0.119 \mathrm{ab}$ & $22.0 \mathrm{~b}$ & $34.8 b$ \\
\hline T4-N-fertilizer & 320,000 & $128 \mathrm{~b}$ & $0.120 \mathrm{a}$ & $21.6 b$ & $36.0 \mathrm{a}$ \\
\hline T5-Inoculated & 80,000 & $334 a$ & $0.112 d$ & $22.7 \mathrm{a}$ & $34.0 c$ \\
\hline T6-Inoculated & 320,000 & $136 \mathrm{~b}$ & $0.116 b c$ & $21.9 b$ & $36.0 \mathrm{a}$ \\
\hline
\end{tabular}

† Means of three crop seasons, each with six replicates. Different letters indicate significant difference (Fisher's test, $p<0.05)$. 
0.116 g per grain with 80,000 plants $\mathrm{ha}^{-1}$ and 0.119 g per grain with 320,000 plants ha ${ }^{-1}$ (Table 6).

In relation to the grain composition, the oil contents were higher in treatments $\mathrm{T} 1$ and $\mathrm{T} 5$ at the low population density, in comparison to treatments T2, T4 and T6 at high density (Table 6). The opposite occurred with protein content (Table 6), indicating an inverse relationship between the percentages of oil and protein in the grains (Pearson's correlation coefficient of $-0.23, p<0.0001)$. No differences in oil and protein content in grains were related to $\mathrm{N}$ treatments (Table 6). Similar to our results, Butler et al. (2010) reported an increase in protein and a decrease in oil content in grains of soybean grown under high population density.

A positive correlation between oil content and sugar availability-especially sucrose-in soybean seeds has been long recognized (Hymowitz et al., 1972). An increase in photosynthate production stimulated by light provides more ATP and C skeletons for fatty acid synthesis in soybean seeds (Willms et al., 1999), and, in our experiment, plants under low population density received more light per plant, resulting in an increase in seed oil content.

Contrarily, protein content in seeds decreased at low density, consistent with several reports, again showing that oil and protein contents in soybean seeds are negatively correlated, attributed to the genetically-determined trade-off between the accumulation of protein and lipids in grain legumes (Kwon and Torrie, 1964; Hymowitz et al., 1972; Brim and Burton, 1979). It has also been known for a long time that protein and oil content in soybean seeds are quantitatively inherited traits, determined by a number of genes subject to genotype $x$ environment interactions (Hwang et al., 2014). In our study, as light received per plant was far less limiting in the low-density treatments, we may assume that neither the photosynthates nor the nutrients (Table 4) were the limiting factors for the competitive synthesis of protein and oil contents. Therefore, differences should rather be attributed to genetic mechanisms controlling these traits. For decades it seemed impossible to breed for increases in both protein and oil contents; however, recently, in a genome-wide association study (GWAS) with 298 soybean germplasm accessions, Hwang et al. (2014) identified 40 single nucleotide polymorphisms(SNPs) associated with seed protein and 25 for oil content, 7 of which had a significant association with both protein and oil. This knowledge may be useful in future efforts to improve both seed quality characteristics.

\section{CONCLUDING REMARKS}

When compared to high density $\left(320,000\right.$ plants ha $\left.{ }^{-1}\right)$, plants under the lower density $\left(80,000\right.$ plants ha $\left.^{-1}\right)$ resulted in larger soybean nodulation and grain oil, but decreased grain protein content per plant. In general, the plant nutritional status was not affected by population density. Noteworthy was that a $75 \%$ reduction in the number of plants per ha resulted in a decrease in grain yield (16\%) in only one out of three cropping seasons. Therefore, further studies should focus on rethinking the common recommendation of high plant density, as a decrease in the number of plants can match the performance of traditional cropping systems with lower risks of adverse effects of biotic and abiotic stresses.

\section{ACKNOWLEDGMENTS}

The study was partially supported by CNPq (Conselho Nacional de Desenvolvimento Científico e Tecnológico, Brazil), Project Repensa (562008/2010-1). Authors acknowledge to Dr. José C. Vieira and Dr. Roberto A. Fioretto from Laborsolo (Londrina, PR), for chemical analysis, Dr. Glaciela Kaschuk for suggestions and Dr. Allan R.J. Eaglesham for English review and suggestions. M.J. de Luca acknowledges a fellowship from CNPq (370481/2012-7) and M. A. Nogueira and M. Hungria are also research fellows from CNPq. Manuscript approved for publication by the Editorial Board of Embrapa Soja (74/2014).

\section{REFERENCES}

Andrade, F.H., P. Calviño, A. Cirilo, and P. Barbieri. 2002. Yield responses to narrow rows depend on increased radiation interception. Agron. J. 94:975-980. doi:10.2134/agronj2002.0975

Ballaré, C.J., andJ.J.Casal.2000.Light signals perceived by cropand weed plants. Field Crops Res. 67:149-160. doi:10.1016/S0378-4290(00)00090-3

Balatti, P.A., and E.R. Montaldi. 1986. Effects of red and far red lights on nodulation and nitrogen fixation in soybean (Glycine max L. Merr). Plant Soil 92:427-430. doi:10.1007/BF02372490

Beaufils, E.R. 1973. Diagnosis and recommendation integrated system (DRIS). A general scheme of experimentation and calibration based on principles developed from research in plant nutrition. Soil Science Bull. 1. Univ. of Natal, Pietermaritzburg, South Africa.

Bellaloui, N., and A.M. Gillen. 2010. Soybean seed protein, oil, fatty acids, N, and $S$ partitioning as affected by node position and cultivar differences. Agric. Sci. 1:110-118 doi:10.4236/as.2010.13014.

Board, J., B.G. Harville, and A.M. Saxton. 1990. Branch and dry weight in relation to yield increase in narrow-row soybean. Agron. J. 82:540-544. doi:10.2134/agronj1990.00021962008200030021x

Board, J., M. Kamal, and B.G. Harville. 1992. Temporal importance of greater light interception to increased yield in narrow-row soybean. Agron. J. 84:575-579. doi:10.2134/agronj1992.00021962008400040006x

Boddey, R.M., J.A.R. Pereira, M. Hungria, R.J. Thomas, and M.C.P. Neves. 1987. Methods for the study of nitrogen assimilation and transport in grain legumes. MIRCEN J. 3:3-32. doi: 10.1007\%2FBF01090491.

Brim, C.A., and J.W. Burton. 1979. Recurrent selection in soybeans. II Selection for increased percent protein in seeds. Crop Sci. 19:494-498. doi:10.2135/cropsci1979.0011183X001900040016x

Butler, J.A., J.L. de Bruin, and P. Pedersen. 2010. Plant density effect on reduced linolenic acid soybean cultivars. Agron. J. 102:348-354. doi:10.2134/ agronj2009.0167

CONAB (Companhia Nacional de Abastecimento/Ministry of Agriculture of Brazil). 2014 www.conab.gov.br/conteudos.php?a=1276\&t=Retrieved in 30/04/2014 (accessed 21 Aug. 2014).

de Luca, M.J., and M. Hungria. 2014. Plant densities and modulation of symbiotic nitrogen fixation in soybean. Sci. Agric. 71:181-187. doi:http://dx.doi.org/10.1590/S0103-90162014000300002

Di Rienzo, J.A., M. Balzarini, L. Gonzalez, F. Casanoves, and M. Tablada. 2009. InfoStat-software estadístico. Univ. Nacional de Córdoba, Córdoba, Argentina.

Embrapa. 1997. Manual de métodos de análise de solo. 2nd. ed. Centro Nacional de Pesquisa de Solos, Rio de Janeiro, Brazil.

Embrapa. 2011. Tecnologias de produção de soja- Região Central do Brasil 2012 e 2013. Embrapa Soja, Sistemas de Produção no. 15, Londrina, PR, Brazil.

Fehr, W., C. Caviness, D.T. Burmood, and J.S. Pennington. 1971. Stage of development descriptions for soybeans, Glycine max (L). Merrill. Crop Sci. 11:929-931. doi:10.2135/cropsci1971.0011183X001100060051x

Harger, N., R. Fioretto, and R. Ralisch. 2003. Evaluation of the soybean nutritional status for the methods of sufficiency level and DRIS. Semin.Ciênc. Agrar. 24:219-224. doi:10.5433/1679-0359.2003v24n2p219

Hungria, M., R.J. Campo, I.C. Mendes, and P.H. Graham. 2006b. Contribution of biological nitrogen fixation to the $\mathrm{N}$ nutrition of grain crops in the tropics: The success of soybean (Glycine max L Merr.) in South America. In: R.P. Singh, N. Shankar, and P.K. Jaiwal, editors, Nitrogen nutrition and sustainable plant productivity. Studium Press, LLC, Houston, TX. p. 43-93. 
Hungria, M., J.C. Franchini, R.J. Campo, C.C. Crispino, J.Z. Moraes, R.N.R. Sibaldelli et al. 2006a. Nitrogen nutrition of soybean in Brazil: Contributions of biological $\mathrm{N}_{2}$ fixation and of $\mathrm{N}$ fertilizer to grain yield. Can. J. Plant Sci. 86:927-939. doi:10.4141/P05-098

Hungria, M., and G. Kaschuk. 2014. Regulation of $\mathrm{N}_{2}$ fixation and $\mathrm{NO}_{3}{ }^{-}$ $\mathrm{NH}_{4}{ }^{+}$assimilation in nodulated and $\mathrm{N}$-fertilized Phaseolus vulgaris L. exposed to high-temperature stress. Environ. Exp. Bot. 98:32-39. doi:10.1016/j.envexpbot.2013.10.010

Hwang, E.-Y., Q. Song, G. Jia, J.E. Specht, D.L. Hyten, J. Costa, and P.B. Cregan. 2014. A genome-wide association study of seed protein and oil content in soybean. BMC Genomics 15:1. doi:10.1186/1471-2164-15-1

Hymowitz, T., F. I.Collins, J. Panczner, and W. M. Walker. 1972. Relationship between the content of oil, protein, and sugar in soybean seed. Agron. J. 64:613-616. doi:10.2134/agronj1972.00021962006400050019x

Instituto Adolfo Lutz. 2008. Normas Analiticas do Instituto Adolfo Lutz. Métodos físico-químicos para análise de alimentos. 4th ed. IMESP, São Paulo, Brazil. p. 122-125.

Johnston, T.J., J.W. Pendleton, D.B. Peters, and D.R. Hicks. 1969. Influence of supplemental light on apparent photosynthesis, yield, and yield components of soybeans (Glycine max L.). Crop Sci. 9:577-581. doi:10.2135/cropsci1969.0011183X000900050018x

Juvany, N., M. Müller, and S. Munné-Bosch. 2013. Photo-oxidative stress in emerging and senescing leaves: A mirror image? J. Exp. Bot. 64:30873096. doi:10.1093/jxb/ert174

Kaschuk, G., M. Hungria, P.A. Leffelaar, K.E. Giller, and T.W. Kuyper. 2010a. Differences in photosynthetic behaviour and leaf senescence of soybean (Glycine max [L.] Merrill) dependent on $\mathrm{N}_{2}$ fixation or nitrate supply. Plant Biol. 12:60-69. doi:10.1111/j.1438-8677.2009.00211.x

Kaschuk, G., T.W. Kuyper, P.A. Leffelaar, M. Hungria, and K.E. Giller. 2009. Are the rates of photosynthesis stimulated by the carbon sink strength of rhizobial and arbuscular mycorrhizal symbioses? Soil Biol. Biochem. 41:1233-1244. doi:10.1016/j.soilbio.2009.03.005

Kaschuk, G., P.A. Leffelaar, K.E. Giller, O. Alberton, M. Hungria, and T.W. Kuyper. 2010b. Responses of legumes to rhizobia and arbuscular mycorrhizal fungi: A meta-analysis of potential photosynthate limitation of symbioses. Soil Biol. Biochem. 42:125-127. doi:10.1016/j.soilbio.2009.10.017

Kaschuk, G., X. Yin, M. Hungria, P.A. Leffelaar, K.E. Giller, and T.W. Kuyper. 2012. Photosynthetic adaptation of soybean due to varying effectiveness of $\mathrm{N}_{2}$ fixation by two distinct Bradyrhizobium japonicum strains. Environ. Exp. Bot. 76:1-6. doi:10.1111/j.1438-8677.2009.00211.x

Kasperbauer, M.J. 1987. Far-red light reflection from green leaves and effects on phytochrome-mediated assimilate partitioning under field conditions. Plant Physiol. 85:350-354. doi:10.1104/pp.85.2.350
Kasperbauer, M.J., P.G. Hunt, and R.E. Sojka. 1984. Photosynthate partitioning and nodule formation in soybean plants that received red or far-red light at the end of the photosynthetic period. Physiol. Plant. 61:549-554. doi:10.1111/j.1399-3054.1984.tb05168.x

Kwon, S.H., and J.H. Torrie. 1964. Heritability of and interrelationships among traits of two soybean populations. Crop Sci. 4:196-198. doi:10.2135/cropsci1964.0011183X000400020023x

Lie, T.A. 1969. Non-photosynthetic effects of red and far-red light on rootnodule formation by leguminous plants. Plant Soil 30:391-404. doi:10.1007/BF01881965

Mabood, F., X. Zhou, and D. Smith. 2006. Bradyrbizobium japonicum preincubated with methyl jasmonate increases soybean nodulation and nitrogen fixation. Agron. J. 98:289-294. doi:10.2134/agronj2005.0132

Neumann, G., and V. Römheld. 2000. The release of root exudates as affected by the plant physiological status. In: R. Pinton, Z. Varanini, and P. Nannipieri, editors, The rhizosphere: Biochemistry and organic substances at the soil-plant interface. 2nd ed. CRC Press, Taylor and Francis Group, Boca Raton, FL, USA. p. 23-72.

Neves, M.C.P., and M. Hungria. 1987. The physiology of nitrogen fixation in tropical grain legumes. Crit. Rev. Plant Sci. 6:267-321. doi: $10.1080 / 07352688709382252$

Pavan, M.A., M.F. Bloch, H.D. Zempulski, M. Miyazawa, and D.C. Zocoler. 1992. Manual de análise química do solo e controle de qualidade. Circular 76. Instituto Agronômico do Paraná, Londrina, PR, Brazil.

Serra, A.P., M.E. Marchetti, D.J. Bungenstab, M.A.G. da Silva, R.P. Serra, F.C.N. Guimarães et al. 2013. Diagnosis and recommendation integrated system (DRIS) to assess the nutritional state of plants. In: M.D. Matovic, editor, Biomass now- sustainable growth and use. InTech, Canada. p. 129-146. doi:http://dx.doi.org/10.5772/54576

Suzuki, A., L. Suriyagoda, T. Shigeyama, A. Tominaga, M. Sasaki, Y. Hiratsuka et al. 2011. Lotus japonicus nodulation is photomorphogenetically controlled by sensing the red/far red (R/FR) ratio through jasmonic acid (JA) signaling. Proc. Natl. Acad. Sci. USA 108:16837-16842. doi:10.1073/pnas.1105892108

Vincent, J.M. 1970. A manual for the pratical study of rooot-nodule bacteria. IBP Handb. 15. Blackwell Scientific, Oxford, UK.

Williams, L.E., T.M. Dejong, and D.A. Phillips. 1982. Effect of changes in shoot carbon-exchange rate on soybean root nodule activity. Plant Physiol. 69:432-436. doi:10.1104/pp.69.2.432

Willms, J.R., C. Salon, and D.B. Layzell. 1999. Evidence for light-stimulated fatty acid synthesis in soybean fruit. Plant Physiol. 120:1117-1128. doi:10.1104/pp.120.4.1117. 